\title{
Federal Habeas Review of Ineff ective Assistance Claims: A Conflict Between Strickland and Stone?
}

The Supreme Court's decision in Stone v. Powell ${ }^{1}$ sharply restricted the ability of state prisoners to obtain federal habeas corpus review of alleged fourth amendment violations. According to the Court, if the prisoner had a "full and fair" opportunity during the state trial to challenge the admissibility of evidence under the fourth amendment, then the state court's ruling on the fourth amendment issue was not subject to habeas review in federal court. $^{2}$ In a more recent habeas case, Strickland $v$. Washington, ${ }^{3}$ the Court recognized that federal courts can and should provide collateral review of a conviction where the prisoner alleges that the inadequacy of his attorney's representation violated the sixth amendment right to counsel. Taken together, these two decisions leave open a puzzling "hybrid" case: a prisoner may seek habeas review of his conviction on the ground that his attorney provided constitutionally inadequate representation because of failure to request exclusion of evidence under the fourth amendment.

Such a case contains a difficult doctrinal conflict. In order to judge the adequacy of counsel under the sixth amendment, a federal habeas court may have to inquire into the substance of the fourth amendment claim. Petitions otherwise foreclosed by Stone could in some cases be recast as ineffective-assistance-of-counsel claims, thus undermining Stone's attempt to reduce duplicative litigation and limit federal interference with "full and fair" state trials. On the other hand, if the attorney's failure to seek exclusion of evidence did in fact constitute inadequate representation, federal habeas review may well be the prisoner's only chance to vindicate the fundamental right to counsel. The tradeoff between these conflicting interests has led the lower federal courts to inconsistent results, ${ }^{4}$ and the Supreme Court recently agreed to resolve the

428 U.S. 465 (1976).

Id. at 494 .

104 S. Ct. 2052 (1984).

- For a discussion of the relevant cases, see infra notes 61-65 and accompanying text. 


\section{controversy. ${ }^{5}$}

Part I of this comment will describe in detail the decisions in Stone and Strickland and their impact on federal habeas corpus review of fourth and sixth amendment claims. Part II will set out an example of a sixth amendment claim grounded in an attorney's failure to raise an exclusionary rule objection and will explain how the federal courts have responded to these hybrid claims. With this background, part III argues that the rationales underlying Stone and Strickland permit federal habeas review of hybrid claims. The comment demonstrates that the hybrid habeas claim does not so significantly implicate the concerns motivating Stone as to justify a bar to review. Instead, the nature of the right to counsel suggests wholly different considerations than were present in Stone, and these considerations largely overshadow the costs of federal review.

\section{Habeas Review of Defaulted Exclusionary Rule Claims}

Federal courts have general jurisdiction over habeas corpus petitions by state prisoners. ${ }^{6}$ Through the writ of habeas corpus, a state prisoner can go to federal court to challenge the constitutionality of his conviction. Often this mechanism allows the federal court to hear claims that have already been adjudicated in state court. ${ }^{7}$ However, judicially created exceptions to habeas jurisdiction have caused reviewability to vary with the particular constitutional provision underlying the challenge. ${ }^{8}$ This variety of stand-

s See Kimmelman v. Morrison, 106 S. Ct. 59, granting cert. to 752 F.2d 918 (3d Cir. 1985).

a "The Supreme Court, a Justice thereof, a circuit judge, or a district court shall entertain an application for a writ of habeas corpus [for a state prisoner] only on the ground that he is in custody in violation of the Constitution or laws or treaties of the United States." 28 U.S.C. $\$ 2254$ (a) (1982). Federal courts are also authorized to hear habeas corpus claims of federal prisoners. Id. $\S 2255$. The availability of the writ is also protected by the Constitution. See U.S. ConST. art. I, § 9.

${ }^{7}$ See, e.g., Wainwright v. Sykes, 433 U.S. 72, 87 (1977) (a federal habeas petitioner is "entitled to have the federal habeas court make its own independent determination of his federal claim, without being bound by the determination on the merits of that claim reached in the state proceedings"); Brown v. Allen, 344 U.S. 443 (1953).

${ }^{8}$ For most constitutional errors the Court has adopted a harmless error test. See, e.g., Chapman v. California, 386 U.S. 18 (1967). However, some types of errors are so fundamental that the Court has refused to find them harmless. See Rushen v. Spain, 414 U.S. 114, 117 n.2 (1983) (citing as an example Gideon v. Wainwright, 372 U.S. 335 (1963)); see also Cuyler v. Sullivan, 446 U.S. 335 (1980) (representation by counsel); Mincey v. Arizona, 437 U.S. 385 (1978) (coerced confession). In other cases the Court has adopted a more lenient stance. See, e.g., Stone v. Powell, 428 U.S. 465 (1976) (denying habeas review unless the defendant was denied a full and fair opportunity to litigate an exclusionary rule claim in state court); McMann v. Richardson, 397 U.S. 759 (1970) (limiting challenges to guilty pleas to assertions of counsel incompetence). See generally LARRY Yackle, Postconviction Remedies \$§ 94-102 
ards complicates the determination of habeas jurisdiction, especially where the petition challenges the conviction on the basis of two intertwined constitutional provisions. Hybrid claims alleging that the defendant was denied adequate assistance of counsel (a sixth amendment issue) because counsel failed to seek the exclusion of illegally seized evidence (a fourth amendment issue) present such a problem. ${ }^{\circ}$

\section{A. Stone v. Powell and the Exclusionary Rule Limitation}

The Supreme Court's 1976 decision in Stone v. Powell ${ }^{10}$ erected a formidable barrier to habeas review of exclusionary rule claims that had been decided on the merits in state court. In Stone, a California court had convicted the defendant of murder despite his contention that the murder weapon was seized in violation of the fourth amendment and therefore testimony concerning this gun should have been excluded from the trial. ${ }^{11}$ After California appellate and supreme courts had affirmed his conviction, the defendant petitioned the federal district court for a writ of habeas corpus. The district court denied the petition, but the Ninth Circuit reversed, finding that the evidence should have been excluded. ${ }^{12}$

The Supreme Court disagreed, holding that federal habeas relief was unavailable to any defendant when "the State has provided an opportunity for full and fair litigation of a Fourth Amendment claim."13 Justice Powell's opinion disclaimed any intention to restrict the general scope of habeas corpus; the decision rested solely on the Court's conclusion that the utility of federal review of exclusionary rule claims was outweighed by its costs. ${ }^{14}$

The Court reasoned that the exclusionary rule imposes significant costs on the criminal justice system. It diverts the trial from the "ultimate question" of guilt or innocence and often frees guilty

(1981) (surveying the harmless error doctrine, and examining the rationale for Stone and its applicability to other judicially created rules for the enforcement of constitutional rights).

- For a hypothetical example of how this kind of case could arise, see text accompanying notes 51-59.

10428 U.S. 465 (1976).

"Id. at 470 . Stone thus differs from the precise issue raised in this comment since Stone did not involve any sort of a procedural default-the fourth amendment claim was fully litigated within the state system.

12 Id. at $470-71$.

13 Id. at 494.

14 Id. at $489-95$. 
defendants by excluding inculpatory evidence. ${ }^{15}$ In the trial setting, these costs are offset by the rule's deterrent effect on police misbehavior-exclusion removes the incentive to make illegal searches and educates the police in their responsibilities under the fourth amendment. ${ }^{16}$ But the Court found these benefits to be marginal at best when federal courts apply the exclusionary rule in a habeas proceeding. Federal review is too attenuated, too far removed from the trial to have a significant effect on police behavior or attitudes. ${ }^{17}$

Two other factors also supported the Court's decision: the need for comity between state and federal courts, and the Court's confidence in state adjudication of constitutional defenses. First of all, by forcing defendants to adjudicate exclusionary rule claims at trial, Stone prevented a good deal of tension between state and federal courts. Although any habeas petition imposes federal review on a state court judgment, exclusionary rule claims allow federal courts to void state convictions on the basis of procedural technicalities that are divorced from the factual determination of guilt or innocence. In the fourth amendment area, then, Stone eliminated an added cost of habeas review-friction between federal and state courts. ${ }^{18}$

Respect for state courts was also reflected in the Court's unwillingness "to assume that there . . . exists a general lack of appropriate sensitivity to constitutional rights in the trial and appellate courts of the several States."19 The Court found "especially unpersuasive" the assertion that federal courts were more competent in adjudicating fourth amendment claims. As the Court noted, "search-and-seizure claims . . . are dealt with on a daily basis by trial level judges in both systems." ${ }^{\text {"20 }}$ Thus, on the benefit side of

\footnotetext{
15 Id. at 490 .

${ }^{16}$ Id. at 493 .

17 Id.
}

18 Id. at 491 n.31 ("Resort to habeas corpus . . . results in serious intrusions on values important to our system of government [including] 'the minimization of friction between our federal and state systems of justice and . . the maintenance of the constitutional balance upon which the doctrine of federalism is founded." ") (quoting Schneckloth v. Bustamonte, 412 U.S. 218, 259 (1973) (Powell, J., concurring)); see also Engle v. Isaac, 456 U.S. 107, 128 n.33 (1982) ("State courts are understandably frustrated when they faithfully apply existing constitutional law only to have a federal court discover, during a $\$ 2254$ proceeding, new constitutional commands [and in] an individual case, the significance of this frustration may pale beside the need to remedy a constitutional violation. Over the long term, however, federal intrusions may seriously undermine the morale of our state judges.").

19 Stone, 428 U.S. at 493 n.35; see also Bator, Finality in Criminal Law and Federal Habeas Corpus for State Prisoners, 76 HaRv. L. Rev. 441, 509 (1963).

${ }^{20}$ Stone, 428 U.S. at 493 n.35. But see Note, Stone v. Powell and the New Federalism: 
Stone's calculus, federal review of exclusionary rule claims offered no advantage of federal expertise. ${ }^{21}$

\section{B. Wainwright v. Sykes and the Procedural Default Limitation}

In Stone the prisoner seeking habeas review had presented his fourth amendment claim in state trial and appellate courts; the Court did not need to address the question of whether the bar would apply to a defendant who had never asserted the claim in state court. A case brought one year later, Wainwright $v$. Sykes, ${ }^{22}$ raised a related issue: a prisoner sought habeas review of a fifth amendment claim on which he had defaulted in state court. The Court barred the petition, stating that such a conviction is subject to federal review only if the prisoner demonstrates "cause" for the default of the claim resulting in "prejudice" to his case. ${ }^{23}$

Sykes had been convicted without raising any objection to the constitutionality of his confession, either at trial or on direct appeal. The objection was first raised in a succeeding motion to vacate his conviction. The state courts refused to hear the claim because the state's "contemporaneous objection" rule required that motions to suppress evidence be made before trial. ${ }^{24}$ Yet, the fed-

A Challenge to Congress, 14 HARv. J. on LEGIS. 152, 162-63 (1976) (arguing that federal judges, because they are insulated by life tenure from political pressure, are better able to adjudicate constitutional claims than are state judges).

21 Criticism of the Court's reasoning on the costs and benefits of direct habeas review of exclusionary rule claims has been extensive. See, e.g., Green, Stone v. Powell: The Hermeneutics of the Burger Court, 10 Creighton L. Rev. 655, 660-63 (1977); Robbins \& Sanders, Judicial Integrity, the Appearance of Justice, and the Great Writ of Habeas Corpus: How to Kill Two Thirds (or More) With One Stone, 15 Am. Crim. L. Rev. 63, 68-76 (1977); Snyder, Habeas Corpus: Stoned But Not Dead, 19 Crim. L. Bull. 197, 198 (1983). One author, who describes Stone favorably as a "utilitarian judgment" based upon plausible premises, nonetheless allows that "the Stone Court can be justly criticized for presenting an insufficient factual base to support its assessment of the costs and benefits of fourth amendment habeas litigation in federal court." Halpern, Federal Habeas Corpus and the Mapp Exclusionary Rule after Stone v. Powell, 82 CoLum. L. REv. 1, 14 (1982).

22433 U.S. 72 (1977).

2s Id. at 87. The Sykes standard, on its face, applies to all defaulted constitutional claims, including exclusionary rule claims.

${ }^{24}$ See id. at 75-77. A state "contemporaneous objection" rule prevents the appellate defendant from raising a constitutional objection that he failed to argue before or during trial. For example, state procedures usually impose a default on defendants who attempt to raise an exclusionary rule claim for the first time on appeal or after the appropriate pre-trial motion period. See, e.g., FLA. R. CRIM. P. 3.190(i)(2) (1985) (restricting time for filing a motion to suppress illegally obtained evidence to the pre-trial period, or, in the court's discretion, during the trial); N.J. CT. R. 3:5-7(a) (1985) (same). The state procedural rule also provides an adequate independent state ground which bars direct review of the federal question by the Supreme Court. See, e.g., Michigan v. Tyler, 436 U.S. 493 (1978); Henry v. Mississippi, 379 U.S. 443 (1965); Michel v. Louisiana, 350 U.S. 91 (1955). 
eral district court stayed Sykes's petition for a writ of habeas corpus pending a factual hearing on the claim in state court, and the Fifth Circuit affirmed on the basis of the Court's decision in Fay v. Noia, ${ }^{25}$ which would have allowed Sykes's petition so long as it was not a "deliberate bypass" of state procedures. ${ }^{26}$

The Supreme Court reversed in spite of Fay, holding that a defendant seeking habeas review of a defaulted claim was required to show both cause for the default and prejudice to his case stemming from that default. ${ }^{27}$ The Court made it clear that the scope of "cause and prejudice" was narrower than the range of available habeas review under Fay's "deliberate bypass" formula. ${ }^{28}$ Sykes thus replaced Fay's presumption in favor of habeas reviewability with a presumption against it.

${ }^{25} 372$ U.S. 391 (1963).

${ }^{26}$ Sykes, 433 U.S. at 77. In Fay, decided fourteen years before Sykes, the Court had ruled that a defendant who allowed the time for a direct appeal to lapse without seeking a state review of the trial court's determination that his confession was not obtained in violation of the fourteenth amendment could still obtain federal habeas relief if the default of his claim did not constitute a "deliberate bypassing" of the state court system. 372 U.S. at 439. This ruling forged an exception to what the Court characterized as the general rule of automatic federal habeas review of federal constitutional claims; if the petitioner was trying to avoid a state court determination of the claim he could be barred from federal review. The Court described this rule as granting federal judges "limited discretion . . . to deny [habeas] relief to an applicant under certain circumstances." Id. at 438.

${ }^{27}$ Sykes, 433 U.S. at 87.

${ }^{28}$ Id. at 87,88 n.12. The Supreme Court elaborated on the definition of "cause and prejudice" in Engle v. Isaac, 456 U.S. 107 (1982), and United States v. Frady, 456 U.S. 152 (1982). In Engle, the Court held that the apparent futility of a constitutional objection at a state trial did not establish cause for the procedural default of that claim. The terms "cause" and "prejudice," according to the Court, are not rigid concepts but are defined in every case according to guiding "principles of comity and finality." Engle, 456 U.S. at 135. Accordingly, the Court rejected both the respondent's argument that the futility of the claim constituted cause for its default and the state's contention that the entire Sykes standard should be supplanted by a simple plain-error inquiry. Id. at 134-35; see also Comment, Habeas Corpus-The Supreme Court Defines the Wainwright v. Sykes "Cause" and "Prejudice" Standard, 19 WAKE Forest L. REv. 441, 461 (1983) ("The construction of 'cause' outlined in Engle will foreclose habeas review in a great number of cases in which the defense attorney's failure to object at trial was the direct result of ignorance or inadvertence.") [hereinafter cited as Comment, Cause and Prejudice]. But see Comment, Federal Habeas Corpus Review of Unintentionally Defaulted Constitutional Claims, 130 U. PA. L. REv. 981, 983 (1982) (proposing that the "cause" requirement "should be deemed satisfied whenever a default is intentional") [hereinafter cited as Comment, Federal Habeas].

In Frady, the Court restated the second prong necessary for review of procedurally defaulted claims as "actual prejudice." 456 U.S. at 168. The Court thus required the petitioner to demonstrate that the default had a demonstrable negative effect on the outcome of the case rather than simply that the default may have prejudiced him. The overall effect of Engle and Frady has been to restrict further the availability of habeas corpus to petitioners who default on constitutional claims. See L. YAckLE, supra note 8, § 86, at 190-91 (1985 Supp.) (noting that Engle's holding may be limited only to cases where counsel is aware of the claim but fails to raise it). 
The Court reasoned that federal habeas review of defaulted claims would destroy state trial and appellate processes. Habeas review would discourage compliance with the state's contemporaneous objection rule, thus sacrificing the rule's benefits: timely presentation of claims and informed appellate review. ${ }^{29}$ The Court also recognized that the contemporaneous objection rule "may lead to the exclusion of the evidence objected to, thereby making a major contribution to finality in criminal litigation." ${ }^{\text {30 }}$ In contrast, the Fay rule encouraged "sandbagging" by defense lawyers who could save federal claims as "last resorts" for federal habeas petitions upon conviction. ${ }^{31}$ The Court was confident that the "cause and prejudice" exception to this general bar would protect defaulting defendants from any "miscarriage of justice."32

\section{The Stone Rule in the Lower Courts}

Stone and Sykes both create rules denying habeas access to the federal courts: Stone denies access for a fourth amendment claim if the defendant had a chance to argue it in state court; Sykes denies access for any claim if the defendant failed to present it at trial within the state's time limits, unless cause and prejudice are shown. For the purposes of defaulted fourth amendment claims, the two decisions could have been interpreted to complement each other. If a claim had been heard on the merits, Stone would bar habeas review. If the defendant failed to make an argument in state court and defaulted under a procedural rule, Sykes would bar habeas review. But if the default occurred with "cause and prejudice" (the Sykes exception), habeas review would be available. In such a case the Stone requirement of a "full and fair" opportunity would not be considered to have been satisfied.

However, lower courts have not read Stone and Sykes in this way. ${ }^{33}$ Instead, they have concluded that the defendant was given a

29 Sykes, 433 U.S. at 88-89; see also L. YACKLE, supra note 8, § 20, at 98 (noting that the rule "encourages counsel to raise claims early in the process, when the trial judge can avoid or mitigate prejudice to the defense. In addition, it ensures that the appellate courts will have the benefit of the trial court's judgment on the merits.").

so Sykes, 433 U.S. at 88.

31 Id. at 89. Thus, the contemporaneous objection rule was an "adequate procedural ground" for barring habeas review. Id. at 86-87; cf. Henry v. Mississippi, 379 U.S. 443, 44749 (1965) (establishing the "adequate procedural ground" rationale for barring federal habeas review).

32 Sykes, 433 U.S. at 91.

ss Indeed, only one district court has restricted the scope of the Stone bar to exclusionary rule claims heard on the merits in state court. See Dunn v. Rose, 504 F. Supp. 1333, 1336-37 (M.D. Tenn. 1981) (characterizing Stone's bar as "res judicata doctrine"). 
"full and fair" opportunity-thus allowing Stone to bar habeas review-even though the default occurred with "cause and prejudice."34 Thus, Stone has been read as a stricter bar to defaulted fourth amendment claims than the general procedural bar set out in Sykes.

The lower courts justify this reading of Stone in several ways. Some argue that Stone's cost-benefit analysis is unchanged by the defendant's failure to raise the exclusionary rule claim in state court; federal habeas review remains an attenuated process unlikely to have much effect on deterrence of police misconduct..$^{35}$ Most also read Stone as reflecting a predominant concern that the state procedures are adequate; they consequently limit themselves to that inquiry. ${ }^{36}$ Finally, some conclude that the Court, by refusing to limit the application of Stone to exclusionary rule claims heard on the merits, has implicitly commanded the extension of Stone to cover procedurally defaulted claims. ${ }^{37}$

Although the lower courts uniformly reject the "cause and prejudice" standard for defaulted fourth amendment claims on habeas review, they disagree about what constitutes a "full and fair" opportunity within the Stone framework. All agree that claims assessed on the merits within the state court system are barred by Stone from habeas review; Stone's facts make this clear. Where the claim was not heard on the merits because of a proce-

34 See, e.g., Brunson v. Higgins, 708 F.2d 1353, 1360-61 (8th Cir. 1983); McPhail v. Warden, Attica Correctional Facility, 707 F.2d 67, 70 (2d Cir. 1983); Hall v. Iowa, 705 F.2d 283, 288 n.2 (8th Cir.), cert. denied, 464 U.S. 934 (1983); United States ex rel. Maxey v. Morris, 591 F.2d 386, 388-89 (7th Cir.), cert. denied, 442 U.S. 912 (1979); Doleman v. Muncy, 579 F.2d 1258, 1265 (4th Cir. 1978); Gates v. Henderson, 568 F.2d 830, 839 (2d Cir. 1977) (en banc), cert. denied, 434 U.S. 1038 (1978); Styers v. Smith, 501 F. Supp. 880, 88789 (W.D.N.Y. 1980), aff'd, 659 F.2d 293 (2d Cir. 1981).

ss See, e.g., Riley v. Gray, 674 F.2d 522, 526 (6th Cir.) ("We perceive no difference in the utility of the exclusionary rule where an opportunity is frustrated because of an inadequate procedural mechanism."), cert. denied, 459 U.S. 948 (1982); Caver v. Alabama, 577 F.2d 1188, 1193 (5th Cir. 1978) ("That a defendant later at trial might choose not to assert his fourth amendment claim could not reduce the system's deterrence to police misconduct."); Gates, 568 F.2d at 840 ("To permit a hearing now eleven years later, after memories have long since dimmed . . . would be neither just to society nor effectuate the rationale of the exclusionary rule-police deterrence.").

${ }^{36}$ See, e.g., Morris, 591 F.2d at 388 (arguing that by providing adequate procedures the state " "has done nothing to deny petitioners the opportunity to fully litigate their Fourth Amendment claims" ") (quoting lower court opinion); Doleman, 579 F.2d at 1264 (Stone bars review if the state provides some "procedural vehicle ('opportunity')" to fully litigate fourth amendment claims).

${ }^{37}$ See, e.g., Gates, 568 F.2d at 838-39 (construing Stone as "effectively overruling Fay with respect to fourth amendment exclusionary rule claims" because the Court recognized that the "exclusionary rule . . . is not a personal constitutional right" and is therefore distinguishable from claims normally subject to habeas review). 
dural bar, many federal courts apply Stone if "the state procedural mechanism, in the abstract, presented the opportunity to raise a fourth amendment claim."38 Thus, the courts make habeas review available only if the "presentation of the claim was in fact frustrated because of a failure of that mechanism." 39 In determining whether the requisite opportunity was available, they ask only whether the state's procedural system was fair as applied in the case at bar.

Other courts have gone further. They have determined that even a procedural error by the state court does not automatically deny the required "full and fair" opportunity to litigate a claim. ${ }^{40}$ A defendant had a "full and fair" opportunity unless the state procedures were "routinely or systematically applied in such a way as to prevent the actual litigation of fourth amendment claims on their merits." 11 If the procedural rules for litigating an exclusionary rule claim are adequate in the abstract, infrequent errors in their implementation do not necessarily mean that the state's system denied defendant the requisite opportunity.

Both of these approaches shift the reviewing court's focus from the possible causes for default of the claim to an analysis of the fairness of the state procedural framework available to the defendant. ${ }^{42}$ Under each approach, the Sykes exception to procedural bars provides no relief from the strict rule in Stone. By refusing to forgive defense mistakes or allow excuses for "good cause," these standards require criminal defendants to invoke the exclusionary rule in the state forum. The only time courts permit fourth amendment claims to be directly reviewed by a federal habeas court is when a systematic breakdown in the state judicial mechanism pre-

so Riley, 674 F.2d at 526.

39 Id.; see also Boyd v. Mintz, 631 F.2d 247, 250 (3d Cir. 1980) (procedural breakdown established where delay in the assignment of defendant's counsel frustrated the filing of a motion to extend time for a suppression motion).

10 See, e.g., Christian v. McKaskle, 731 F.2d 1196, 1199 (5th Cir. 1984); Locks v. Sumner, 703 F.2d 403, 408 (9th Cir.), cert. denied, 464 U.S. 933 (1983); Sneed v. Smith, 670 F.2d 1348, 1355-56 (4th Cir. 1983); Lenza v. Wyrick, 665 F.2d 804, 808-09 (8th Cir. 1981); Williams v. Brown, 609 F.2d 216, 220 (5th Cir. 1980).

11 Williams, 609 F.2d at 220.

42 See, e.g., Hubbard v. Jeffes, 653 F.2d 99, 103 (3d Cir. 1981) (prohibiting habeas review because counsel's failure to investigate a fourth amendment claim "was not brought about by any restriction of the opportunity [to raise the claim] by the state courts"); Boyd v. Mintz, 631 F.2d 247, 250 (3d Cir. 1980) ("Stone only requires that the state provide the opportunity irrespective of whether the defendant avails himself of it"); see also L. YACKLE, supra note 8, \$99, at 389 ("Put plainly, Stone holds that it makes no difference why the default occurred or what the consequences of the default may have been. Stone establishes a rigid rule that failure to employ a state motion to suppress is fatal."). 


\section{Strickland v. Washington and the Ineffective Assistance of Counsel Limitation}

By emphasizing the state trial and appellate courts as the appropriate place to assert constitutional defenses, Stone and Sykes have increased the importance of the criminal defendant's right to adequate counsel. The attorney's failure to raise a fourth amendment claim can effectively bar any review of the claim on the merits, both in state court and on direct habeas review by the federal courts. ${ }^{44}$ This raises the possibility that an attorney's failure to pursue the fourth amendment claim could itself become the basis for a habeas challenge.

In Strickland v. Washington ${ }^{45}$ the Supreme Court recognized that a prisoner may use habeas corpus to challenge the adequacy of trial counsel..$^{46}$ Applying established sixth amendment principles

13 See Stone, 428 U.S. at 493 n.35. One commentator has asserted that the standard is a "direct outgrowth of Professor Bator's insistence that the central role for habeas corpus is not to assure that federal questions are correctly decided, but to assure that they are decided by procedures calculated to reach a correct decision." Seidman, Factual Guilt and the Burger Court: An Examination of Continuity and Change in Criminal Procedure, 80 Colum. L. REv. 436, 458 (1980); see Bator, supra note 19, at 509 (emphasizing that "[t]here is no intrinsic reason why the fact that a man is a federal judge should make him more competent, or conscientious, or learned with respect to the applicable federal law than his neighbor in the state courthouse"); see also L. YACKLE, supra note 8, §99, at 391-93 ("At bottom, some courts seem to have concluded that fourth amendment exclusionary rule claims are no longer thought to be important enough to warrant reexamination of any kind in federal habeas corpus. Errors, procedural or substantive, made by the state in adjudicating such claims can be corrected by the Supreme Court on direct review-or not at all."); $c f$. Sykes, 433 U.S. at 90 ("[T] the trial of a criminal case in a state court [is] a decisive and portentious event. . . . To the greatest extent possible all issues . . . should be determined in this proceeding.").

14 See Strazzella, Ineffective Assistance of Counsel Claims: New Uses, New Problems, 19 ARIz. L. REv. 443, 482 (1977); Tague, Federal Habeas Corpus and Ineffective Representation of Counsel: The Supreme Court Has Work To Do, 31 STaN. L. Rev. 1, 61-62 (1978).

${ }_{45} 104 \mathrm{~S}$. Ct. 2052 (1984). Strickland is one of several post-Stone cases to consider the standards for habeas review without confronting, as did Stone, whether review should exist at all. See 3 W. LaFave \& J. Israet, Criminal Procedure $\S 27.3$, at 318 (1985).

$10104 \mathrm{~S}$. Ct. at 2062-63; see infra note 57 (discussing the right to effective counsel). Prior to Strickland, the federal circuits used a variety of tests in habeas review of sixth amendment claims. All but three circuits required a showing of some type of "prejudicial incompetence"; that is, more than just ineffectiveness of counsel in the abstract. See Comment, Effective Assistance of Counsel: The Sixth Amendment and the Fair Trial Guarantee, 50 U. CHI. L. REv. 1380, 1402 (1983). Only one circuit continued to use the "mockery of justice" standard, requiring petitioner to demonstrate that his counsel's incompetence, on the whole, denied his right to a fair trial. See United States v. Bubar, 567 F.2d 192, 202 (2d Cir.), cert. denied, 434 U.S. 872 (1977).

The lower courts also differed about the level of prejudice which had to be shown before 
in the habeas setting, the Court set forth a two-prong test similar to that in Sykes. First, the sixth amendment requires "reasonably effective assistance" by counsel in criminal defenses. ${ }^{47}$ The Court reasoned that more specific guidelines were inappropriate given the "variety of circumstances faced by defense counsel [and] the range of legitimate decisions regarding how best to represent a criminal defendant." sixth amendment as "ensur[ing] that criminal defendants receive a fair trial," rather than attempting to improve the quality of counsel, lower courts should "indulge a strong presumption" of adequacy. ${ }^{48}$

Second, the Court found that the petitioner had to show that the ineffective counsel prejudiced the outcome of the trial. Emphasizing the fair trial purpose of the sixth amendment, the Court required the defendant to show that, based on the totality of the evidence, "there is a reasonable probability that, but for counsel's unprofessional errors, the result of the proceeding would have been different." Bo Because the determination of the effectiveness of

relief could be granted. Some required that the ineffectiveness be so egregious that it would determine the outcome of the case, see, e.g., United States v. DeCoster, 624 F.2d 196, 208, 211-12 (D.C. Cir.) (en banc), cert. denied, 444 U.S. 944 (1979), while others adopted a "conceivable effect on the trial" test, see, e.g., Cooper v. Fitzharris, 586 F.2d 1325, 1333 (9th Cir. 1978) (en banc), cert. denied, 440 U.S. 974 (1979). An exhaustive list of cases applying the various standards may be found in Washington v. Strickland, 673 F.2d 879, 896-900 \& nn.11-20, rev'd, 693 F.2d 1243 (5th Cir. 1982) (en banc), rev'd, 104 S. Ct. 2052 (1984). See generally Comment, supra, at 1385-1408 (discussing the various sixth amendment approaches to the right to competent counsel).

47 Strickland, 104 S. Ct. at 2064.

${ }^{48} \mathrm{Id}$. at 2065.

40 Id. at 2065-66.

so Id. at 2067-69. In selecting the "reasonable probability" standard, the Court discussed and rejected the application of either a "some conceivable effect on the trial" or "outcome-determinative" standard for the prejudice prong of the test. Id. at 2067-68, 2068; see supra note 46. See generally Comment, supra note 46, at 1381, 1419-23 (suggesting that the right to representation which does not cast doubt on the reliability of the verdict "is found not in the sixth amendment but in the fair trial guarantee of the due process clause").

It should be noted that the Strickland standard is more stringent than the Sykes "cause and prejudice" standard. Courts have recognized a number of attorney errors with labels such as "inexperience," Rachel v. Bordenkircher, 590 F.2d 200, 204 (6th Cir. 1978), and "unintentional action," Garrison v. McCarthy, 653 F.2d 374, 377 (9th Cir. 1981), that do not reach a sufficient level of egregiousness to violate the standards for effectiveness of counsel but do establish "cause" for the default. See, e.g., Carrier v. Hutto, 724 F.2d 396, 400 (4th Cir. 1983), aff'd, 754 F.2d 520 (en banc), cert. granted, 105 S. Ct. 3523 (1985); Runnels v. Hess, 653 F.2d 1359, 1364 (10th Cir. 1981). But see Palmes v. Wainwright, 725 F.2d 1511, 1525 (11th Cir.) (only ignorance of counsel "yielding manifest injustice" will satisfy cause), cert. denied, $105 \mathrm{~S}$. Ct. 374 (1984). In contrast, the presumption of competence established by Strickland will, if overcome, always establish cause for a default. See Comment, Cause and Prejudice, supra note 28, at 453 ("As a general rule, when the defendant 
counsel is a "mixed question of law and fact," the Court held that on habeas review a federal court could reevaluate the record in assessing whether the sixth amendment had been violated. ${ }^{51}$

\section{The Availability of Federal Habeas Review: A Conflict}

Because the lower courts apply Stone's bar even in cases of procedural default, a person who is convicted after his attorney neglected to raise a fourth amendment claim at trial will be likely to cast his habeas petition as a sixth amendment issue. In this situation, the habeas court's application of Strickland seems to permit the very result that Stone was intended to prohibit: federal review on the merits of exclusion.

To illustrate, suppose that Jones is convicted in state court. At trial, the prosecution offers evidence that could be excluded because it was seized in violation of the fourth amendment..52 Whether for tactical reasons or through inadvertence or incompetence, Jones's lawyer fails to object to admission of the evidence. On direct appeal of Jones's conviction, the state's contemporaneous objection rule prohibits Jones from raising any new issues, thus barring state appellate review of the fourth amendment issue. ${ }^{53}$

Jones would also be barred from seeking federal habeas review of the fourth amendment issue. Under Stone, federal courts will not provide habeas review if the state "provided an opportunity for full and fair litigation of a Fourth Amendment claim."54 As most courts have interpreted Stone, review of Jones's claim would be

fails to receive constitutionally mandated effective assistance of counsel, cause has been found.").

Strickland's requirement that the petitioner show a "reasonable probability that, but for counsel's unprofessional errors, the result of the proceeding would have been different," $104 \mathrm{~S}$. Ct. at 2068, might at first glance seem less stringent than the "actual prejudice" now required for defaults, United States v. Frady, 456 U.S. 152, 172 (1982). But the lower courts' treatment of "prejudice" under Strickland has been extremely restrictive. In reviewing the effect of counsel performance on the "result of the proceeding" they have denied habeas relief in most cases, even those in which the courts assumed that attorney performance fell below constitutional standards. See, e.g., Stokes v. Procunier, 744 F.2d 475, 481 (5th Cir. 1984) (assuming arguendo that attorney performance was ineffective, court denied review by ruling that defendant failed to show that but for the ineffectiveness the result would have been different); see also infra note 94 (listing cases).

51 Strickland, 104 S. Ct. at 2070 (citation omitted). Usually, under the habeas statute federal courts must presume that state court findings of fact are correct. See 28 U.S.C. $\S 2254$ (d) (1982).

${ }^{32}$ See, e.g., Mapp v. Ohio, 367 U.S. 643, 655 (1961) ("[A]ll evidence obtained by searches and seizures in violation of the Constitution is . . . inadmissible in a state court.").

ss "Contemporaneous objection" rules are discussed supra at note 24.

s4 Stone, 428 U.S. at 494. 
barred even though he did not raise it, as long as he had the opportunity to raise it at the state trial. ${ }^{55}$ Thus, because of Stone and the contemporaneous-objection rule, a failure to raise the constitutional claim at trial becomes a permanent bar to later review of the fourth amendment claim in any court.

In this particular situation, however, Jones has a different claim. Jones may be able to challenge the attorney's omission itself as a constitutional violation. ${ }^{.6}$ The sixth amendment guarantees Jones the effective assistance of a lawyer, ${ }^{57}$ and in Strickland the Supreme Court determined that this right may serve as a basis for federal habeas review. If Jones's lawyer prejudiced the case by failing to provide "reasonably effective assistance," Jones may be entitled to a new trial. ${ }^{58}$

In evaluating Jones's sixth amendment claim, the reviewing court may have to inquire into the merits of his fourth amendment claim in order to determine whether the attorney's failure to object was incompetent and prejudicial to Jones. ${ }^{59}$ Seeking a writ under the Strickland rule thus might allow Jones to obtain federal review of fourth amendment issues that Stone would have barred if sought directly. ${ }^{60}$

One response to this dilemma is to treat the hybrid claim the same way that most lower courts have treated Sykes-type defaults of fourth amendment claims: apply the Stone bar in spite of the

${ }^{35}$ See supra notes $33-44$ and accompanying text.

ss See Tague, supra note 44, at 57-60 (suggesting that failure to object is frequently evidence of incompetence).

s7 "In all criminal prosecutions, the accused shall enjoy the right . . . to have the Assistance of Counsel for his defence." U.S. ConsT. amend. VI. The right to counsel has been interpreted to include "the right to effective assistance of counsel." McMann v. Richardson, 397 U.S. 759, 771 n.14 (1970).

ss Strickland, 104 S. Ct. at 2064; see also Trapnell v. United States, 725 F.2d 149, 15152 (2d Cir. 1983). Issuance of the writ by the reviewing court usually entitles the defendant to a new trial. See L. YACKLE, supra note 8, § 141, at 531.

Of course, Jones may be able to raise the sixth amendment claim in state court by attacking the original trial judgment either on appeal or through a collateral proceeding. In many instances, however, this possibility is unavailable, see infra note 99 and accompanying text, and in others it will prove fruitless if the court refuses to consider any evidence outside the trial record, see L. YACKLE, supra note 8, $\S 6$, at 21 ; Tague, supra note 44, at 60 n.286. Thus, Jones may be unable to raise this claim by any means other than a federal habeas petition.

s9 See, e.g., Morrison v. Kimmelman, 752 F.2d 918, 922 (3d Cir. 1985), cert. granted, 106 S. Ct. 59 (1985); Stokes v. Procunier, 744 F.2d 475, 483 (5th Cir. 1984); see also Tague, supra note 44, at 65 ("The habeas court must still develop the facts relevant to the motion that counsel did not make.").

"See Comment, supra note 46, at 1406 \& n.113 ("This can be done with great ease and with virtually any claim."); see also Strazzella, supra note 44, at 482; Tague, supra note 44 , at $56-57$. 
Strickland standard. In a case decided a few years before Strickland, the Second Circuit adopted this approach. ${ }^{61}$ In denying a hybrid writ, the court held that the petition should be reviewed under Stone's standard of a "full and fair" opportunity, without any inquiry into the competence of the attorney or prejudice that may have resulted from the attorney's omission. ${ }^{62}$ The court reasoned that "at the heart of [the] case lies an alleged fourth amendment violation" and that the petitioner's strategy sought "the same remedy of exclusion" of the evidence by adding a sixth amendment claim "for good measure." 63 In the court's view, any review of the ineffective assistance claim would undermine Stone's bar on habeas review of fourth amendment claims. In essence, the circuit court saw the hybrid petition as seeking the same review and remedy as a direct fourth amendment petition, and thus entailing the same costs found to be unacceptable in Stone. Courts adopting this approach would be assuming that the incompetence of counsel never deprives the defendant of a "full and fair" opportunity to litigate his fourth amendment claim.

Most other courts confronted with the issue have declined to bar review. ${ }^{64}$ They reason that Stone's focus on whether there was a "full and fair" opportunity to present the fourth amendment claim in the state court neither requires investigation into the reasons behind the default nor takes account of the quality of counsel. ${ }^{65}$ But a claim of ineffective assistance of counsel raises both these issues. Therefore, these courts have adjudicated hybrid claims under either the two-prong test laid down in Strickland, which assesses both the reasons for the ineffectiveness and the effect it had on the trial, or under the various standards for ineffective assistance in use prior to Strickland.

${ }^{61}$ See LiPuma v. Commissioner, 560 F.2d 84, 93 \& n.6 (2d Cir.), cert. denied, 434 U.S. 861 (1977); see also Allah v. Henderson, 526 F. Supp. 282, 285-86 (S.D.N.Y. 1981), aff'd, 697 F.2d 287 (2d Cir. 1982) (following LiPuma, but indicating its result would be different were it able to write on a "clean slate"). But see 3 W. LAFAVE \& J. IsRAEL, supra note 45, § 27.3, at 326-27 \& $n .93$ (suggesting that default of exclusionary rule claims probably bars all review unless defendant argues incompetency of counsel as a separate constitutional claim).

${ }^{62}$ LiPuma, 560 F.2d at 93 n.6.

is Id.

64 See, e.g., Morrison v. Kimmelman, 752 F.2d 918, 922 (3d Cir.), cert. granted, $106 \mathrm{~S}$. Ct. 59 (1985); Goodwin v. Balkcom, 684 F.2d 794, 820 n.24 (11th Cir. 1982), cert. denied, 460 U.S. 1098 (1983); Sallie v. North Carolina, 587 F.2d 636, 640 (4th Cir. 1978), cert. denied, 441 U.S. 911 (1979); cf. Fornash v. Marshall, 686 F.2d 1179, 1188 n.11 (6th Cir. 1982) ("We are assuming without deciding that Stone . . . does not apply to a claim of ineffective assistance of counsel which is grounded in trial counsel's failure to assert a Fourth Amendment claim."), cert. denied, 460 U.S. 1042 (1983).

${ }^{65}$ See, e.g., Morrison, 752 F.2d at 921-22; Sallie, 587 F.2d at 640-41. 


\section{The Effect of Strickland on the Habeas Standards DEVELOPED UNDER Stone}

Several factors suggest that this latter approach-declining to bar review-is correct. Most importantly, to apply the Stone bar to sixth amendment petitions would vastly underestimate the stakes inherent in such claims. The right to adequate counsel is crucial to a fair judicial process, and thus is not easily subsumed into Stone's balancing approach. Even if that important difference were ignored, the costs associated with hybrid claims are far less than those present in direct fourth amendment claims. Moreover, hybrid petitions raise little prospect of abuse; the rigor of the Strickland test gives defendants every incentive to present their fourth amendment claims at trial. Finally, unlike direct fourth amendment claims, hybrid petitions do not raise the dangers to federalism that the Court feared in Stone.

\section{A. The Benefits of Hybrid Claim Review}

A hybrid petition contains an important element missing from a direct fourth amendment claim: an allegation that the defendant was denied the right to counsel. The Supreme Court's decisions since Stone suggest that this crucial fact makes the Stone bar inapplicable to hybrid claims.

In Rose v. Mitchell, ${ }^{86}$ a majority of the Court rejected Stone for purposes of a habeas petition based upon the equal protection clause. Mitchell claimed that the grand jury proceeding leading to his indictment was tainted by racial selection. ${ }^{67}$ But since no trial error was alleged, his petition, like the one in Stone, did not challenge the fairness of his trial. ${ }^{68}$ Nevertheless, the Court hesitated to frame the question, as it had in Stone, in terms of whether Mitchell had a "full and fair" opportunity to present the fourteenth amendment claim in the state trial or appeal.

Describing Stone as "carefully limited" to fourth amendment claims, the Court found the fourteenth amendment claim to be fundamentally different. ${ }^{69}$ After all, the Court reasoned, the right against racial discrimination in the administration of justice is "substantially more compelling" than a claim for exclusion of evi-

68443 U.S. 545 (1979).

67 Id. at 548 .

6s See id. at 582 (Powell, J., concurring in the judgment).

os Id. at 564 . 
dence. ${ }^{70} \mathrm{~A}$ challenge to the impartiality of the indictment process brings the fairness of the state judiciary and criminal justice system under scrutiny. ${ }^{71}$ Since habeas relief helps to protect the legal system from injuring "fundamental values of our society," its benefits in the equal protection area more than exceed its costs. ${ }^{72}$ Moreover, the traditional practice of federal courts hearing discrimination challenges in habeas petitions helped to minimize the possibility that review of claims like those in Mitchell would cause friction between the states and the federal government. ${ }^{73}$

In Jackson $v$. Virginia, ${ }^{74}$ similar reasoning led the Court to allow habeas review of a due process claim that had been fully and fairly heard in state court. Jackson maintained that his conviction was based on insufficient evidence and thus violated due process. ${ }^{75}$ Unlike the exclusionary rule claim in Stone, the Court said, Jackson's claim was "central to the basic question of guilt or innocence." ${ }^{\prime 76}$ Stone's bar thus did not apply.

These cases might be understood to stand for either of two different principles. On the one hand, they may implicitly limit Stone's bar to cases involving exclusionary rule claims, and refuse to extend it to any case involving "personal constitutional rights." Indeed, the majority in Stone was particularly careful to emphasize that its holding applied only to claims involving the exclusionary rule, which is "a judicially created remedy rather than a personal constitutional right."77 On the other hand, they may reject Stone's bar only in cases where the rights involved are crucial to the fairness of the judicial proceeding. Habeas review must remain available for claims based on such rights, because a denial of those rights always implicates the validity of the conviction. Such claims by their very nature question the defendant's "opportunity for . . . full and fair litigation." "78

No matter which of these principles is understood to govern Mitchell and Jackson, the two cases indicate that habeas review of hybrid claims should be permitted. Even if these two cases stand only for the combined and thus more limited proposition that the

\footnotetext{
${ }^{70} \mathrm{Id}$.

71 Id.

${ }^{72} I d$, at 564

${ }^{73} \mathrm{Id}$. at 562 .

74443 U.S. 307 (1979).

7s Id. at 312 .

${ }^{76} \mathrm{Id}$. at 323.

37 Stone, 428 U.S. at 494 n.37.

${ }^{78} \mathrm{Id}$. at 494 .
} 
Stone bar applies to all claims except claims founded on personal constitutional rights which are crucial to the fairness of the judicial proceeding, a hybrid petition alleging a sixth amendment violation falls within this narrow category.

This is so because the right to counsel, like the rights to equal protection and due process, implicates sufficiently weighty concerns about individual rights and fairness to suggest that a trial in which counsel was constitutionally inadequate can never be a "full and fair" proceeding that, under Stone, is not subject to habeas review. The right to counsel is one of the most important rights that the Constitution expressly provides to individual citizens. ${ }^{79} \mathrm{It}$ is through this right alone that many other rights are secured; without adequate counsel, individuals would be at a loss in attempting to protect their other rights, particularly in those instances where they are forced to rely on litigation as their last resort. ${ }^{80}$ The Supreme Court has recognized that the "right to counsel exists, and is needed, in order to protect the fundamental right to a fair trial."

The sixth amendment deprivation alleged in a hybrid claim is immediate and direct, and threatens the defendant's "full and fair" opportunity to vindicate his rights. The Supreme Court has noted that "[a]n ineffectiveness claim . . . is an attack on the fundamental fairness of the proceeding whose result is challenged." A claim of ineffective assistance inevitably raises the crucial question of "whether counsel's conduct so undermined the functioning

79 See, e.g., Cuyler v. Sullivan, 446 U.S. 335, 343 (1980) ("The right to counsel guaranteed by the sixth amendment is a fundamental right."); Gideon v. Wainwright, 372 U.S. 335, 344 (1963) ("The right of one charged with crime to counsel may not be deemed fundamental and essential to fair trials in some countries, but it is in ours.").

The Supreme Court has also recognized the particular importance of the right to counsel in other contexts. For example, the Court is more circumspect in allowing waiver of this right than in allowing waiver of other rights. Compare Farretta v. California, 422 U.S. 806 (1975) (requiring a knowing and intelligent waiver of right to counsel), with Wainwright v. Sykes, 433 U.S 72 (1977) (allowing waiver of claims by procedural default). Also, when the right to counsel was applied to the states through the fourteenth amendment it was made retroactive, see Linkletter v. Walker, 381 U.S. 618 (1964), unlike other rights, which were not, see, e.g., Desist v. United States, 394 U.S. 244 (1969) (exclusionary rule); Johnson v. New Jersey, 384 U.S. 719 (1966) (privilege against self-incrimination).

so See, e.g., Strickland, 104 S. Ct. at 2063; Powell v. Alabama, 287 U.S. 45, 68-69 (1932).

s1 Strickland, 104 S. Ct. at 2063; see also Adams v. United States ex rel. McCann, 317 U.S. 269, 279 (1942) ("The public conscience must be satisfied that fairness dominates the administration of justice . . . Essential fairness is lacking if an accused cannot put his case effectively in court.").

s2 Strickland, $104 \mathrm{~S}$. Ct. at 2070. The Court also noted that "fundamental fairness is the central concern of the writ of habeas corpus." Id. 
of the adversarial process that the trial cannot be relied upon as having produced a just result."83 Therefore, although the exclusionary rule claim foreclosed by counsel incompetence may not by itself justify the costs of collateral review, the need to protect the defendant's right to counsel does provide adequate justification. ${ }^{84}$

${ }^{83}$ Id. at 2064; see also Pillette v. Foltz, 580 F. Supp. 1290, 1295 (E.D. Mich. 1984) ("It is clear that a defendant is deprived of a full and fair litigation of the merits of his or her Fourth and Fifth Amendment claims when he or she is not afforded effective assistance of counsel."); Note, Stone v. Powell and the Effective Assistance of Counsel, 80 Mich. L. REv. 1326, 1341 (1982) (same).

In Hill v. Lockhart, $106 \mathrm{~S}$. Ct. 366 (1985), the Supreme Court recently reaffirmed the independent importance of habeas review of ineffectiveness claims. There the Court extended Strickland's two-part test to ineffective assistance claims arising out of the plea process. Id. at 370. The Court held that such a challenge was independent of the general test for determining the voluntariness of guilty pleas. Id. at 369 .

84 See, e.g., Morrison v. Kimmelman, 752 F.2d 918, 921-22 (3d Cir.) ("The exclusionary rule is simply a judicially created chastisement to deter police misconduct. The right to effective assistance of counsel, however, is firmly embedded in the Constitution to protect defendants, assure a fair trial, and further the search for truth. Stone is the culmination of years of justified questioning of and speculation about the efficacy, not of the Fourth Amendment, but of the exclusionary rule. On the other hand, there has never been any doubt about the absolute necessity of effective counsel."), cert. granted, $106 \mathrm{~S}$. Ct. 59 (1985).

One might argue that the sixth amendment's guarantee of effective assistance of counsel is intended only to advance the accuracy of the trial outcome, and not to promote fairness to the defendant. Cf. Strickland, $104 \mathrm{~S}$. Ct. at 2064 (a fair trial is "a trial whose result is reliable"). Were this true, a hybrid claim could never result in a finding of a sixth amendment violation, since the failure to exclude even illegally seized evidence would not cast doubt on the factual accuracy of the trial's outcome. The problem with this view, however, is that it subverts the Court's current understanding of both the sixth amendment and the purpose of habeas review.

There is no question that the sixth amendment's counsel guarantee is meant to be more than a device to enhance trial accuracy. The right to counsel was made applicable to the states as a component of fourteenth amendment due process, which is a broad guarantee of fairness. See Gideon v. Wainwright, 372 U.S. 335, 344 (1963). This guarantee gives the accused more than the mere right to an accurate verdict; it requires that when the state brings its powers to bear against an individual, the state will be held to a procedure that is fair in and of itself. Hence the Court has consistently enforced the right to counsel at all critical stages of the criminal proceeding, even those unrelated to the trial or its accuracy. See Powell v. Alabama, 287 U.S. 45, 69 (1932) (defendant "requires the guiding hand of counsel at every step in the proceedings against him.") (emphasis added), quoted with approval in United States v. Cronic, 104 S. Ct. 2039, 2043 n.8 (1984); see also Brewer v. Williams, 430 U.S. 387, 398-99 (1977) (excluding self-incriminating statements obtained in absence of counsel). Insofar as hybrid claims assert the right to counsel, they implicate fairness concerns of a constitutional scope even where counsel ineffectiveness does not bear on the trial's accuracy.

An approach to hybrid claims that focuses solely on accuracy of outcome would not only be at odds with sixth amendment law, but would also overturn Stone's guarantee of a "full and fair" opportunity to litigate the exclusionary-rule claim. Stone, 428 U.S. at 494. A full and fair opportunity to litigate is one in which the defendant has a meaningful chance to argue defenses that would have affected the outcome of the trial, not merely those which question the accuracy of the outcome. Cf. supra notes 66-73 and accompanying text (discussing Rose v. Mitchell, 443 U.S. 545 (1979)). It would be manifestly unfair to the defend- 
Finally, a bar to hybrid claims would be all the more inappropriate given the central role of attorney competence in a regime of restricted habeas review. The Court's determination that state courts should be the primary forums for the evaluation of constitutional defenses ${ }^{85}$ places a premium on the quality of trial counsel. Trial errors may forever bar consideration of constitutional claims. ${ }^{86}$ Immunizing counsel errors from habeas review would have little or no effect on the efficacy of counsel and thus would not tend to strengthen the state court's ability to fulfill its role as the primary forum. ${ }^{87}$ Rather, the effect of barring habeas review would be to require defendants to comply with strict state procedural rules while denying them recourse to federal review of criti-

ant if counsel's ineffectiveness would prevent the defendant from ever having an opportunity to raise an exclusionary-rule claim that -if Strickland's stringent prejudice standard could be met-had a "reasonable probability" of affecting the outcome of the trial. Cf. Powell, 287 U.S. at 69 ("Left without the aid of counsel he may be put on trial without a proper charge, and convicted upon incompetent evidence, or evidence irrelevant to the issue or otherwise inadmissible.") (emphasis added), quoted with approval in Cronic, $104 \mathrm{~S}$. Ct. at 2043 n.8. Such an approach would elevate ex post knowledge about actual guilt above the defendant's right to a full determination of "legal guilt" through the adversary system. See Comment, supra note 46, at 1420-21 ("The fair trial guarantee inherent in due process requires that a defendant be given a new trial whenever he shows that counsel's acts or omissions are likely to have adversely affected the outcome of this trial and hence his legal guilt.").

Moreover, if the Court were to bar habeas review of sixth amendment claims only where the alleged error undermines the reliability of the outcome at trial, it would be forced to make a cumbersome distinction between ineffectiveness claims grounded on different bases depending on whether those claims could have any effect on the reliability of the result at trial. This would call into question the reviewability of counsel errors relating to such matters as grand jury and other pre-trial proceedings, certain rules of evidence, see, e.g., FED. R. Evid. $407 \&$ advisory committee notes (promoting the social policy of encouraging people to take safety measures); FED. R. CRIM. P. 11(e)(6) \& advisory committee notes (promoting the public policy favoring settlement of disputes); IrL. Rev. STAT. ch. 110A, § 402(f) (1985) (same), and particular time limits or other rules that promote the orderliness or efficiency of trial proceedings.

${ }^{85}$ See Sykes, 433 U.S. at 90; Stone, 428 U.S. at 494-95 \& n.35; see also supra notes 1821, 29-32 and accompanying text.

s6 See supra notes 53-60 and accompanying text.

${ }_{87}$ The lower court cases that have refused to apply Sykes to unadjudicated exclusionary rule claims, see supra notes $33-42$ and accompanying text, can be distinguished in this context. In those cases, the failure to comply with state procedural rules was not a result of attorney incompetence; thus, the defendant had a "full and fair" opportunity to raise the claim but did not do so. Allowing direct habeas review of fourth amendment claims in such cases would undermine the validity of state procedural rules. In contrast, in hybrid claims the defendant was denied a "full and fair" opportunity to raise the claim because the attorney was incompetent. Foreclosing review in these cases would allow the attorney's mistakes to prevent the state court from hearing and deciding the claim. In the first situation, the failure to raise the claim is part and parcel of the state's judicial process; in the second, the failure to raise the claim undermines the essential fairness of the state proceedings. 
cal mistakes that their attorneys commit during the trial. ${ }^{88}$

\section{B. The Real Costs of Federal Review of Hybrid Petitions}

Not only are there great benefits to allowing habeas review of hybrid sixth amendment claims, but the costs of allowing such claims are significantly lower than the costs of direct review that the Court sought to avoid in Stone. Of course, categorical denial of hybrid claims under Stone's "full and fair" test would reduce even further the chance that habeas review will lead to exclusion of inculpatory evidence in a new trial on remand. But, as the previous section argues, the fundamental nature of the right to counsel indicates that the savings that would be achieved by such a bar are insufficient to justify its considerable costs.

Assuming, then, that the Stone bar does not apply to hybrid claims, the habeas court will consider the merits of the fourth amendment claim only as an incident to determining the adequacy of counsel. The federal court itself will not decide the fourth amendment issue, which is not properly before it and for which there is no state court record. Instead, the court will only review the sixth amendment claim; it will apply Strickland to determine whether counsel's failure to object to evidence was both unreasonable and prejudicial. And in practice, the court can apply this standard through a three-step inquiry which minimizes the need to consider the merits of the fourth amendment claim.

First, the court should determine whether the circumstances of the case were such that even if the defendant had properly raised and prevailed on the fourth amendment claim there would have been no change in the eventual outcome of the trial. In many cases, failure to raise the claim is a harmless error which could not constitute prejudice to the defendant. ${ }^{89}$ This inquiry does not re-

${ }^{88}$ See Note, supra note 83, at 1338-39 ("Indeed, because federal courts can no longer fully review the merits of state court rulings, a habeas court should be especially concerned with the quality of a defendant's representation during the 'main event'-the state trial.") (emphasis in original). The negligence of counsel should not be attributed to the defendant under an "agency" theory. There is a "systematic divergence between the interests of defendants and their counsel" that compels reviewing courts to scrutinize the client-counsel relationship despite the intrusion into the state criminal system. Cover \& Aleinikoff, Dialectical Federalism: Habeas Corpus and the Court, 86 Yale L.J. 1035, 1083 (1977).

${ }^{89}$ See Tague, supra note 44, at 65-66 ("If the habeas court decides that the issue lacked merit, or that the failure to raise the issue did not actually prejudice the defendant, the court could deny the ineffectiveness challenge without determining why counsel did not object. But if the habeas court cannot deny the petition on those grounds, it must then determine why counsel did not object."); see also Keys v. Duckworth, 761 F.2d 390, 394 (7th Cir. 1985) (counsel's failure to investigate witnesses was not ineffective given petitioner's 
quire the court to go into the merits of the fourth amendment claim at all.

If the fourth amendment claim could have affected the outcome of the trial, the court should next determine whether the trial counsel provided "reasonably effective assistance" to the defendant..$^{30}$ The "strong presumption" that counsel was adequate, ${ }^{91}$ combined with the myriad of competent reasons for an attorney's failure to object, ${ }^{22}$ make it very difficult for the defendant to satisfy this prong of Strickland's test. The court may find it necessary at this point to look into the merits of the fourth amendment claim in order to assess whether the failure to object was reasonable.

Finally, if the case has survived these two steps, ${ }^{93}$ the court

inability to suggest any prejudice from that failure); Cousart v. Hammock, 745 F.2d 776, 778 (2d Cir. 1984) (noting that a lack of actual prejudice is sufficient to deny the petition without inspecting the counsel's performance); Stokes v. Procunier, 744 F.2d 475, 481-83 (5th Cir. 1984) (no Strickland prejudice in counsel's failure to object to Miranda violation where defendant gave contradictory statements after arrest, was identified as the burglar by two eyewitnesses, and had burglary tools on his person when apprehended); Martin v. Maggio, 739 F.2d 184, 187 (5th Cir.) (no jury would accept the defense theory that counsel supposedly should have used at trial), cert. denied, $105 \mathrm{~S}$. Ct. 447 (1984).

${ }^{20}$ Strickland, 104 S. Ct. at 2064.

sI Id. at 2065-66.

.2 For example, the sixth amendment does not protect the petitioner from counsel's tactical failures. See L. YACKLE, supra note $8, \S 86$, at 349. Courts have tended to distinguish inadvertent omission from "tactical" refusal, holding that when counsel deliberately fails to raise a claim, "cause" will not be shown unless that tactic constituted ineffective assistance in itself. See, e.g., Carrier v. Hutto, 724 F.2d 396, 401, 403 (4th Cir. 1983), aff'd, 754 F.2d 520 (en banc), cert. granted, 105 S. Ct. 3523 (1985); Runnels v. Hess, 653 F.2d 1359, 1363-64 (10th Cir. 1981); Garrison v. McCarthy, 653 F.2d 374, 377 (9th Cir. 1981); cf. Jones v. Barnes, 463 U.S. 745, 750-54 \& n.7 (1983) (appellate defense counsel did not have a sixth amendment duty to raise every nonfrivolous issue requested by the defendant, because of the need to winnow out weaker arguments and the limited amount of time and space available to the appellate advocate in making his case).

In addition, the intention of the attorney to present a "candid and forthright" defense and his assessment of the futility of a fourth amendment claim are reasons for supporting court findings that a failure to raise the claim does not always mean a counsel is incompetent. See Fornash v. Marshall, 686 F.2d 1179, 1188 (6th Cir. 1982), cert. denied, 460 U.S. 1042 (1983); see also Inge v. Procunier, 758 F.2d 1010, 1016 (4th Cir.), cert. denied, 106 S. Ct. 104 (1985); Taylor v. Maggio, 727 F.2d 341, 348 (5th Cir. 1984).

9s The cases that reach the third step in the analysis will be cases in which: 1) the fourth amendment issue, if it had been raised, would have affected the outcome of the case; and 2) the attorney's failure to raise the claim was unreasonable. To illustrate, suppose that $D$ is charged with murder, and there is evidence indicating that the murder weapon, a gun, was obtained unlawfully by the police. If the prosecution had sufficient other evidence-an eyewitness, for example-to convict $D$ even if the gun was excluded, then the failure to exclude was harmless error and the case would not survive the first step. Or, even if the gun was the only evidence, but $D$ 's attorney's failure to object to its admission was a tactical decision, then the failure was "reasonable" and the case would not survive the second step. However, $D$ 's claim would reach the third step if exclusion of the gun would have disabled the prosecution's case and the attorney's failure to object was caused by incompetence. 
must determine whether the defendant's claim was sufficiently likely to succeed on the merits that the attorney's failure to raise the claim could have prejudiced the outcome. ${ }^{94}$ Under Strickland, the court must find a "reasonable probability" that the outcome of the original trial would have been different if counsel had raised the fourth amendment claim. One might think that this standard is met only if a defendant can show that he actually would have succeeded in excluding the evidence. If this were correct, the habeas court would have to decide the merits of the fourth amendment claim. But this view misstates the degree of certainty necessary to satisfy the "prejudice" prong of Strickland. In cases where the exclusion of the challenged evidence could have affected the outcome of the trial, the Strickland standard is satisfied if the defendant can show that he had a "reasonable probability" of succeeding on the fourth amendment claim. If the defendant does so, then he should be found to have been prejudiced by his counsel's unreasonable failure to raise the claim. At this point the habeas court can remand the case to the state court for a new trial and, if necessary, full consideration of the fourth amendment claim.

This three-step analysis shows how the habeas court can review a hybrid claim according to the Strickland test without improperly attempting to decide the fourth amendment issue itself. For several reasons, the overall costs associated with this approach to habeas review of hybrid claims will be far less than the costs imposed by direct review. First, in a large number of hybrid claims, the habeas court will never reach the merits of the fourth amend-

Then the court would have to look into the merits of the exclusionary rule claim to determine whether $D$ was prejudiced under the Strickland standard.

84 The following post-Strickland cases represent a small fraction of those in which federal courts have refused to grant a writ on the basis that counsel errors have not constituted "prejudice" to the defendant: United States v. Fuller, 769 F.2d 1095, 1099 (5th Cir. 1985) (counsel's incorrect representation of maximum sentence to defendant who entered a guilty plea did not undermine fairness of proceedings); Adams v. Wainwright, 764 F.2d 1356, 136769 (11th Cir. 1985) (various attorney failures all found not to be prejudicial under Strickland); Hobbs v. Blackburn, 752 F.2d 1079, 1082 (5th Cir. 1985) (stating that the "ultimate focus of the inquiry must be on the fundamental fairness of the challenged proceeding"), cert. denied, 106 S. Ct. 117 (1985); United States v. Resnick, 745 F.2d 1179, 1188 (8th Cir. 1984) (attorney disclosure of incriminating documents to prosecutor was not prejudicial); Tucker v. Zant, 743 F.2d 775, 780 (11th Cir. 1984) (even though attorney's conduct was "woefully inadequate," court need not pass on ineffectiveness claim because no prejudice was shown). Strickland prejudice has been found in only a handful of cases. See, e.g., Morrison v. Kimmelman, 752 F.2d 918, 919 (3d Cir.) (failure to conduct any discovery), cert. granted, 106 S. Ct. 59 (1985); Smith v. Wainwright, 741 F.2d 1248, 1254-55 (11th Cir. 1984) (failure to impeach accomplice's testimony), cert. denied, $105 \mathrm{~S}$. Ct. 1853 (1985); Harris v. Kuhlman, 601 F. Supp. 987 (E.D.N.Y. 1985) (failure to perfect appeal within seven and onehalf years). 
ment claim. Unlike direct review of exclusion claims, which inevitably requires examination of the merits, many hybrid cases will be weeded out during the first two steps outlined above, on the grounds that counsel was "reasonably effective" or that no prejudice to the defendant could possibly have occurred. Second, in virtually all of the hybrid cases the fourth amendment claims were never even raised in state court, much less argued or decided. In such cases, a habeas court's examination of these claims, if necessary, would not be a repetitive hearing of issues already litigated in state court, as is true of direct review of most fourth amendment claims. Finally, and most importantly, because the habeas court does not decide the fourth amendment claims, review in hybrid cases will never result in a federal court judgment that orders a state court to exclude inculpatory evidence. Review of hybrid claims thus does not give defendants a "back door" into federal court; it neither undermines the effect of Stone nor creates the costs that that decision was intended to prevent.

\section{Potential for Abuse}

As a practical matter, the prospect of habeas review of a sixth amendment claim based on the default of an exclusionary rule claim does not encourage attorneys to "sandbag" the exclusionary rule claim at trial. Any such strategy would impose great and certain immediate costs on the defendant in exchange for remote and uncertain benefits. By deliberately allowing damaging evidence to be admitted at trial, an attorney might greatly increase the risk of a conviction. If the attorney tried to raise this issue later, Stone would bar direct habeas review. As a last resort, then, the attorney might frame the issue as a sixth amendment claim..$^{95}$ However, as a close look at Strickland's standard has shown, incidental review of the fourth amendment claim offers little assurance that the evi-

Qs It is also important to recognize that sandbagging would require attorneys to be unrealistically devious. Credible claims of ineffective assistance cannot be brought by the same attorney whose performance is challenged. Sandbagging a Strickland claim thus would require that the trial attorney anticipate both that he will be removed from the case, and that another attorney (or the prisoner) will impugn his performance by following through on the claim years later. Moreover, the time pressures felt by most criminal attorneys, especially those in the understaffed public defender's office, suggest that most procedural defaults are unintentional, not strategic. See Comment, Federal Habeas, supra note 28, at 996-98. A further reason why sandbagging is unlikely is that ineffective assistance is not the sort of claim for which the trial attorney can "develop" a record for collateral attack. Ineffective assistance claims usually turn on evidence outside the record. See Tague, supra note 44, at $59-60$. 
dence would ever be excluded.

In addition, serious ethical considerations prevent an attorney from deliberately providing inadequate representation. Indeed, as the Strickland Court noted, the maintenance of legal ethical standards is generally "sufficient to justify the law's presumption that counsel will fulfill the [adversary] role [effectively]."96 Since current ethical standards expressly prohibit an attorney from waiving or failing to assert a claim unless he makes a defensible "professional judgment" that waiver is in the client's best interest, ${ }^{97}$ it is unnecessary to extend Stone to guard against such strategic action.

\section{Federalism}

The federalism concerns that influenced the Court's cost-benefit analysis in Stone-confidence in the ability of state courts to adjudicate constitutional claims and the desire to avoid friction between state and federal courts-point in the opposite direction when the habeas claim is one of ineffective assistance of counsel. Here the state court never had the opportunity to rule on the fourth amendment issue. ${ }^{98}$ And the habeas petition challenges the precise deficiency-incompetence of counsel-that prevented the state court from ruling on that issue.

Of course, if the ineffectiveness of counsel is immediately apparent, defendant could raise the issue on appeal of the trial court judgment. But often the defendant will not understand or appreciate his attorney's incompetence and its impact on the trial unless a more knowledgeable party-such as another attorney-reviews the trial court record at a later time. Although in some states an ineffective-counsel claim could then be raised in a collateral attack on the original judgment, in a number of other states the collateral court would refuse to consider evidence outside the record in gaug-

${ }^{96}$ Strickland, $104 \mathrm{~S}$. Ct. at 2065.

9z See Model Code of Professional Responsibitity DR 7-101(A)(1), 7-101(B)(1) (1981). The ethical codes may also require that an attorney conform his behavior to the rules of the court. See Model Rules of Professional Conduct Rule 3.4(c) (1983) ("A lawyer shall not . . . knowingly disobey an obligation under the rules of a tribunal except for an open refusal based on an assertion that no valid obligation exists."); MODEL CodE OF ProFESSIONAL RESPONSIBILITY DR 7-106(c)(7) (1981) ("In appearing in his professional capacity before a tribunal a lawyer shall not . . . intentionally or habitually violate any established rule of procedure or of evidence.").

${ }_{88}$ The true friction between state and federal courts is generated when the state court has already ruled on the merits of the issue, as it had in Stone. See Bator, supra note 19, at 509 ("Why should a federal court hear cases even if they do involve these important rights? The answer is, of course, clear where state courts will not-and are not compelled to-hear them at all or under fair circumstances.") (emphasis added). 
ing the validity of the defendant's claim, or perhaps permit no later claim at all.99 In either situation, however, the defendant's sixth amendment petition implicates the essential fairness of the state court proceeding, which fully justifies federal habeas review. ${ }^{100}$

Furthermore, a hybrid claim does not denigrate the state's procedural rules. Its challenge goes not to the validity of those rules, but to the attorney's inability to comply with them. As long as they provide a "full and fair" opportunity for litigation, the rules continue to protect the conviction from federal collateral attack. Unless his counsel is ineffective, the petitioner may be legitimately frustrated by the state's procedural mechanism from raising the fourth amendment claim. ${ }^{101}$ In short, the review of hybrid petitions, by enforcing compliance with state procedural rules, enhances the comity between federal and state courts.

\section{Conclusion}

Allowing federal habeas corpus review of hybrid claims under Strickland's test for ineffective assistance of counsel is not inconsistent with Stone's prohibition of direct habeas review of exclusionary rule claims. Indeed, the approach used by the Court in Stone-balancing the benefits of allowing direct review against the costs-itself requires that review of hybrid claims should be allowed. Given the fundamental importance of the right to counsel, the benefits from review of hybrid claims are clearly greater than the benefits of direct review of exclusionary rule claims. Review of hybrid claims will also prove less costly than review of Stone claims, as the court will neither rehear issues already litigated in

" See Tague, supra note 44, at $60 \mathrm{n} .286$ ("On direct appeal an appellate court will usually consider only those issues presented by the trial record and will not accept any additional evidence."); L. YACKLE, supra note 8, §6, at 21 (many states do not permit collateral attack on issues that have been or could have been decided on appeal); see also id. $\S \S 5$ 6, 10-11.

${ }^{100}$ For example, in Strickland the Court reviewed a habeas petition alleging ineffective assistance that first had been raised and rejected in state court as a collateral attack on the trial judgment. See $104 \mathrm{~S}$. Ct. at 2058-59; see also id. at 2070 ("An ineffective assistance claim . . . is an attack on the fundamental fairness of the proceeding whose result is challenged [and] fundamental fairness is the central concern of the writ of habeas corpus."). Federalism concerns are also mitigated because the long tradition of federal courts hearing habeas claims involving sixth amendment issues helps to minimize the friction that federal review of such claims might cause between state and federal courts. Cf. Rose v. Mitchell, 443 U.S. 545, 562 (1979) (making the same argument for habeas review of discrimination claims).

${ }^{101}$ Riley v. Gray, 674 F.2d 522, 526 n.3 (6th Cir.), cert. denied, 459 U.S. 948 (1982). 
state court nor actually decide the fourth amendment claim. And since habeas attention to counsel incompetence would bolster the role of state courts in judging constitutional defenses, federalism concerns also favor review. Finally, habeas review of hybrid claims under the Strickland standard will not open a "back door" into federal court for defendants with exclusionary rule claims. Rather, habeas review helps to ensure that defendants are not denied a "full and fair" hearing in state court, and does so without imposing the costs of direct review identified in Stone.

Kevin J. O’Brien 